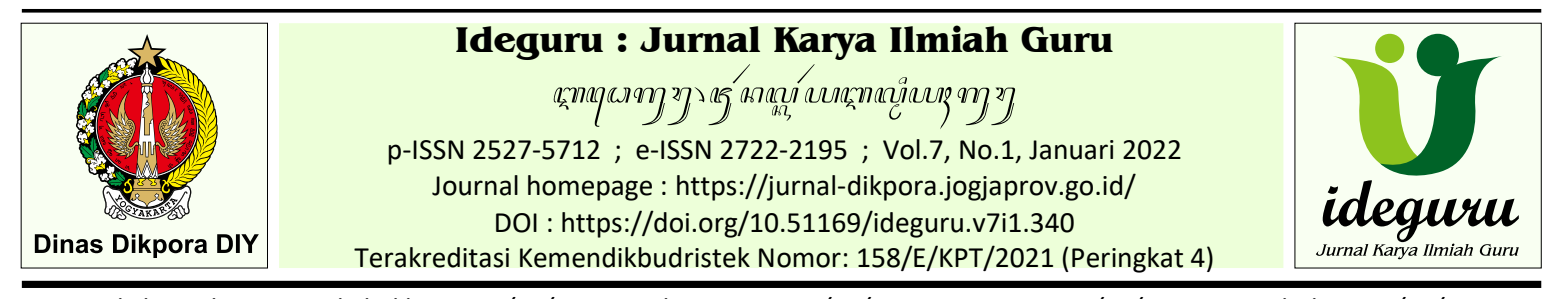

Artikel Penelitian - Naskah dikirim: 14/12/2021 - Selesai revisi: 30/12/2021 - Disetujui: 31/12/2021 - Diterbitkan: 01/01/2022

\title{
Peningkatan Self Regulation Learning melalui Layanan Bimbingan Belajar Daring Model STAD Berbantuan Media Thinglink
}

\author{
Malthelda Yulianti \\ SMA Negeri 2 Yogyakarta, Yogyakarta, Daerah Istimewa Yogyakarta, Indonesia \\ Antin.yuli@gmail.com
}

\begin{abstract}
Abstrak: Penelitian ini bertujuan untuk meningkatkan self regulation learning peserta didik melalui layanan bimbingan belajar daring model Student Teams Achievement Divisions (STAD) berbantuan media thinglink. Subyek penelitian adalah peserta didik kelas XI MIPA-1 SMA Negeri 2 Yogyakarta tahun pelajaran 2020/2021. Jenis penelitian yang dilaksanakan merupakan Penelitian Tindakan Kelas Bimbingan Konseling (PTK BK) yang mengikuti model Stephen Kemmis dan Robin McTaggart, melalui tahapan perencanaan (planning), tindakan (acting), pengamatan (observing), dan refleksi (reflecting). Metode penelitian adalah observasi dengan menggunakan instrumen yang disusun peneliti dengan mengacu pada kajian teori yang digunakan. Teknik analisis data mengunakan teknik deskriptif kualitatif, yakni mendeskripsikan pelaksanaan layanan bimbingan belajar daring model STAD berbantuan media thinglink dari tahap perencanaan, pelaksanaan tindakan, observasi dan refleksi pada setiap siklus. Hasil penelitian menunjukan bahwa ada peningkatan kemampuan self regulation learning peserta didik, pada aspek metakognisi sebelum tindakan berada pada posisi 77.20\%, setelah tindakan siklus II menjadi 89.90\% meningkat sebesar $12.70 \%$. Pada aspek motivasi sebelum tindakan 76.70\% setelah tindakan siklus II meningkat menjadi $87.40 \%$, peningkatan pada aspek motivasi sebesar $10.70 \%$. Selanjutnya pada aspek perilaku sebelum dilakukan tindakan sebesar $74 \%$ setelah tindakan siklus II menjadi 83.30\%. Peningkatan indikator pada aspek perilaku meningkat 9.30\%. Dari hasil penelitian tindakan kelas bimbingan konseling ini dapat disimpulkan bahwa layanan bimbingan belajar daring model STAD berbantuan media thinglink dapat meningkatkan self regulation learning peserta didik kelas XI MIPA-1 SMA Negeri 2 Yogyakarta.
\end{abstract}

Kata kunci: self regulation learning; layanan bimbingan belajar daring; STAD berbantuan media thinglink.

\section{Improving Self Regulation Learning through Online Tutorial Services STAD assisted Media Thinglink Mode}

\begin{abstract}
This study aims to improve students' self-regulation learning through online tutoring services with the Student Teams Achievement Divisions (STAD) model assisted by media thinglink. The research subjects were students of class XI MIPA-1 SMA Negeri 2 Yogyakarta in the 2020/2021 academic year. The type of research carried out is Action Research for Counseling Classes (PTK BK) which follows the model of Stephen Kemmis and Robin McTaggart, through the stages of planning, acting, observing, and reflecting. The research method is observation using an instrument prepared by the researcher with reference to the study of the theory used. The data analysis technique uses a qualitative descriptive technique, which describes the implementation of online tutoring services with the STAD model assisted by media thinglink from the planning, action implementation, observation and reflection stages in each cycle. The results showed that there was an increase in students' self-regulation learning abilities, in the metacognitive aspect before the action was in the position of $77.20 \%$, after the second cycle of action became $89.90 \%$ increased by $12.70 \%$. In the aspect of motivation before the action, $76.70 \%$ after the second cycle of action increased to $87.40 \%$, the increase in the motivational aspect was $10.70 \%$. Furthermore, in the behavioral aspect before the action was taken, 74\% after the second cycle of action became $83.30 \%$. Improved indicators on behavioral aspects increased by $9.30 \%$. From the results of this counseling class action research, it can be concluded that the online tutoring service model of the STAD assisted by media thinglink can improve the self-regulation learning of students in class XI MIPA-1 SMA Negeri 2 Yogyakarta.
\end{abstract}

Keywords: self regulation learning; online tutoring service; STAD assisted by media thinglink. 


\section{Pendahuluan}

Bimbingan konseling di sekolah bertujuan untuk membantu semua peserta didik memahami diri sendiri dan lingkungannya, mengembangkan potensinya, memiliki keterampilan menghadapi masalah dan mempunyai perencanaan hidup secara bijaksana dalam bidang pribadi, sosial, belajar dan karir. Sukiman (2011: 109) menjelaskan beberapa strategi mencapai tujuan tersebut dapat dilakukan melalui berbagai layanan yakni: orientasi, informasi, penempatan dan penyaluran, bimbingan belajar, konseling perorangan, konseling kelompok, bimbingan kelompok, dan mediasi.

Pada masa pandemik Covid-19 saat ini peserta didik hampir empat semester mengikuti proses pembelajaran dari rumah masing-masing, dengan pendekatan secara daring maupun luring sesuai dengan pendekatan yang diterapkan oleh sekolah (SE Mendikbud No. 15 Tahun 2020). Dalam kondisi pembelajaran daring, merujuk pendapat Nasution dan Abdillah (2019: 118) perlu memberikan layanan bimbingan belajar yang memungkinkan peserta didik menjadi terbiasa dengan sikap dan kebiasaan belajar yang baik, memahami kecepatan dan ketidakmampuan yang mereka alami dalam belajar, dan berbagai aspek tujuan belajar lainnya. Fungsi utama dari layanan bimbingan belajar adalah pengembangan.

Salah satu nilai yang perlu dikembangkan dalam proses layanan bimbingan belajar adalah self regulation learning atau regulasi diri dalam belajar, yakni usaha membantu peserta didik mengelola kemampuan belajarnya melalui pengaturan diri yang terarah pada pencapaian tujuan, dengan menyesuaikan perubahan yang terjadi di lingkungan secara dinamis; contohnya pada masa darurat Covid-19 peserta didik perlu menata ulang konsep belajarnya.

Konsep ideal pembelajaran berdasarkan regulasi diri menurut pendapat Alsa (dalam Savira dan Suharsono, 2013: 68) merupakan mekanisme pengembangan dan pemantauan diri terhadap pikiran, perasaan dan perilaku untuk mencapai tujuan belajar, dapat mengelola waktu dan mampu mengendalikan diri untuk fokus pada sistem pembelajarannya, yang dalam istilah psikologi disebut self regulation learning.

Menurut Zimmerman (dalam Yasdar dan Muliyadi, 2018: 52). Pengertian self regulation learning yakni tindakan proaktif untuk mengatur metakognitif, motivasi dan perilaku untuk mencapai tujuan dan berkinerja lebih baik. Dari pengertian tersebut dapat diartikan bahwa aspekaspek self regulation learning untuk diaplikasikan dalam belajar meliputi; 1) Metakognitif adalah pemahaman dan kesadaran peserta didik tentang kemampuan berfikirnya. 2) Motivasi merupakan kebutuhan dasar untuk mendorong dan mengontrol kemampuan yang ada pada setiap diri individu. 3) Perilaku adalah upaya individu untuk mengatur diri, menyeleksi, memanfaatkan dan menciptakan lingkungan yang mendukung aktifitas belajarnya.

Mengamati proses layanan bimbingan belajar yang guru Bimbingan Konseling (BK) laksanakan di kelas XI MIPA-1 SMA Negeri 2 Yogyakarta masih ditemukan kondisi atau perilaku peserta didik yang mencerminkan self regulation learning rendah. Gejala tersebut adalah; sebagian besar peserta didik sering terlambat bergabung di kelas BK, sebagian peserta didik terlambat mengumpulkan refleksi dari layanan bimbingan belajar, dan sebagian besar peserta didik kesulitan mengelola aktivitas belajarnya, yang menyebabkan hasil belajarnya kurang optimal sehingga menimbulkan rasa cemas dan stres.

Kondisi tersebut menggambarkan bahwa keterlibatan peserta didik dalam layanan bimbingan belajar di kelas belum maksimal. Guru BK harus segera mengatasi permasalahan tersebut karena kalau dibiarkan menyebabkan tujuan layanan bimbingan belajar dan proses penanaman nilai-nilai tidak dapat tercapai dengan optimal. Berdasarkan wawancara dengan beberapa peserta didik faktor yang menyebabkan self regulation learning rendah adalah: 1) peserta didik mulai merasa jenuh dan bosan mengikuti pembelajaran daring karena banyak tugas, 2) peserta didik sering tergoda menghabiskan waktu untuk bermain gadget, 3) peserta didik kurang konsentrasi saat mengikuti layanan bimbingan belajar, 4) peserta didik merasa kesulitan mengelola aktivitas belajarnya sehingga tidak maksimal dalam menyelesaikan tugas-tugas yang menjadi tanggungjawabnya.

Untuk meningkatkan self regulation learning peserta didik, peneliti memilih menggunakan layanan bimbingan belajar daring model STAD. Model pembelajaran ini pertama kali dikembangkan oleh Robert Slavin dan temantemannya di Universitas John Hopkin, model pembelajaran ini merupakan variasi dari pembelajaran kooperatif (Shoimin, 2017: 48). Model pembelajaran STAD menurut pendapat Rusman (2012: 215) terdiri dari enam sintak, yakni: a. Menyampaikan tujuan dan memotivasi, b. Pembagian kelompok, c. Presentasi dari guru, d. Kegiatan belajar dalam tim, e. Evaluasi, dan $\mathrm{f}$. Penghargaan prestasi tim.

Dengan model pembelajaran STAD peneliti akan menggali dan mencari solusi dalam 
mengatasi rendahnya self regulation learning peserta didik. Beberapa hasil penelitian membuktikan bahwa penggunaan pembelajaran kooperatif dalam tim seperti STAD dapat meningkatkan prestasi belajar, meningkatkan keterampilan sosial, meningkatkan kemampuan untuk menerima kelemahan diri sendiri dan orang lain, dan meningkatkan harga diri. Selain itu, pembelajaran kooperatif dapat mengidentifikasi kebutuhan peserta didik ketika belajar, berpikir, dan memecahkan masalah (Slavin dalam Sanjaya, 2013: 242).

Dalam menyampaikan layanan bimbingan belajar guru BK dituntut kreatif dan inovatif memilih media pembelajaran. Guru BK memilih menggunakan media thinglink sebagai media pembelajaran online karena sangat menarik dan aktual. Thinglink adalah salah satu media website yang menyediakan berbagai macam fitur-fitur menarik yang bisa di-setting dan digunakan sebagai media pembelajaran secara online (Zain Fuadi, 2020). Kelebihan dari media Thinglink hampir semua media online yang ada dapat ditautkan ke media ini. Media seperti video, gambar, audio, You Tube, Google Forms, link seperti ideaboardz.com dapat disematkan di media thinglink ini. Media thinglink, menarik dan multi fungsi, karena guru dapat dengan cepat memberikan materi penjelasan melalui video, gambar, audio, dan lainnya. Selain itu, guru dapat menyematkan link Google Forms atau wordwall.net sebagai bahan evaluasi siswa (Zain Fuadi, 2020).

Dalam layanan bimbingan belajar daring model STAD berbantuan media thinglink akan membantu peserta didik mengembangkan sikap dan kebiasaan belajar yang baik sesuai kondisinya, materi meliputi; pemahaman potensi diri, bakat, minat, sikap, kekuatan-kekuatan dalam belajar, kelemahan-kelemahan dan penanggulangannya, dan usaha-usaha pencapaian cita-cita. (Sukardi, dalam Nasution HS dan Abdillah, 2019: 118).

Munculnya berbagai permasalahan yang telah dipaparkan di atas, mendorong peneliti untuk melakukan penelitian dengan judul" Peningkatan Self Regulation Learning Melalui Layanan Bimbingan Belajar Daring Model STAD Berbantuan Media Thinglink Pada Peserta didik Kelas XI SMAN 2 Yogyakarta Tahun 2020/2021"

Berdasarkan latar belakang diatas, maka yang menjadi rumusan masalah pada penelitian ini adalah: Apakah layanan bimbingan belajar daring model STAD berbantuan media thinglink dapat meningkatkan self regulation learning pada peserta didik kelas XI MIPA-1 SMA Negeri 2 Yogyakarta? dan Bagaimana penerapan layanan bimbingan belajar daring model STAD berbantuan media thinglink dapat meningkatkan self regulation learning pada peserta didik kelas XI MIPA-1 SMA Negeri 2 Yogyakarta?

Tujuan Penelitian ini untuk mengetahui peningkatkan self regulation learning melalui layanan bimbingan belajar daring model STAD berbantuan media thinglink pada peserta didik kelas XI MIPA-1 SMA Negeri 2 Yogyakarta, dan mengetahui penerapan layanan bimbingan belajar daring model STAD berbantuan media thinkling dapat meningkatkan self regulation learning pada peserta didik kelas XI MIPA-1 SMA Negeri 2 Yogyakarta.

Hasil penelitian ini diharapkan dapat memberikan manfaat bagi peserta didik dalam upaya meningkatkan kemampuan self regulation learning-nya; bagi guru BK layanan bimbingan belajar daring model STAD berbantuan media thinglink dapat sebagai alternatif dalam membimbing peserta didik agar mempunyai kemampuan self regulation learning yang baik, sedangkan bagi sekolah dapat sebagai masukan bahwa layanan bimbingan belajar daring model STAD berbantuan media thinglink dapat sebagai alternatif dalam menanamkan nilai-nilai kehidupan khususnya nilai self regulation learning.

\section{Metode Penelitian}

Jenis penelitian ini merupakan penelitian tindakan kelas bimbingan konseling (PTK BK) mengikuti model Stephen Kemmis dan Robin Mc Taggart. Prosedur penelitian dilaksanakan dengan siklus dan masing-masing siklus melalui tahapan perencanaan, tindakan, observasi dan refleksi dalam satu spiral yang saling terkait (Sukiman 2011: 138). Subjek dan tempat penelitian adalah peserta didik kelas XI MIPA-1 SMA Negeri 2 Yogyakarta, berjumlah 36 peserta didik terdiri 18 laki-laki dan 18 perempuan. Penentuan subjek penelitian berdasarkan pada permasalahan yang teridentifikasi pada saat layanan bimbingan belajar di kelas. Pelaksanaan penelitian dari April 2021 sampai Juni 2021. Pengambilan data dilaksanakan selama 4 kali tatap muka. Setiap tatap muka selama 3 jam pelajaran daring ( $1 \mathrm{JP}$ selama 30 menit). Dalam melaksanakan penelitian peneliti dibantu seorang observer. Penelitian ini dilaksanakan dalam dua siklus, Siklus I dilaksanakan untuk mengatasi rendahnya kemampuan self regulation learning peserta didik. Siklus II dilaksanakan untuk menindaklanjuti hasil refleksi dari siklus I, sehingga setelah akhir siklus II diharapkan kemampuan self regulation learning peserta didik meningkat. 


\section{Tahapan tindakan siklus I}

Prosedur PTK BK tahapan perencanaan meliputi: menyusun RPL BK sesuai sintak STAD berbantuan media thinglink, menyusun instrumen observasi, membentuk kelompok di google classrrom, mengunggah di google classroom format presensi, pre-test, link untuk mengakses materi di media thinglink, LKPD, Lembar kerja kelompok (LKK), dan post-test, menginformasikan kode akses kelas BK, serta link untuk google meeting di grup kelas.

Tahap melaksanakan tindakan pertemuan 1; dilaksanakan hari Kamis, 29 April 2021 selama 3 jam pelajaran melalui aplikasi google classroom diawali dengan google meeting dilanjutkan dengan belajar secara interaktif menggunakan media thinglink. Indikator kompetensi dasar bimbingan: menanamkan konsep self regulation learning beserta aspeknya. Melalui media thinglink peserta didik dibimbing memahami makna self regulation learning serta aspeknya, mengerjakan LKPD, dan dibimbing memahami prosedur belajar dalam tim secara daring yang efektif.

Pertemuan 2; dilaksanakan hari Jumat, 30 April 2021 selama 3 jam pelajaran dengan aplikasi google classroom, diawali dengan google meeting. Indikator kompetensi dasar bimbingan: analisis kemampuan self regulation learning. Peserta didik dibimbing membuat analisis tentang aktivitas belajarnya dalam LKK, dan mengerjakan post-test. Kemudian peneliti mengevaluasi dan memberi penghargaan pada peserta didik yang hasil belajarnya bagus.

Tahapan observasi; peneliti dengan dibantu seorang guru sebagai observer, mengobservasi proses pelaksanan layanan bimbingan belajar daring model STAD berbantuan media thinglink dengan menggunakan instrumen aktivitas guru BK, serta mengamati aktivitas peserta didik dalam mengikuti layanan bimbingan belajar daring model STAD berbantuan media thinglink menggunakan instrumen aktivitas peserta didik, untuk mengobservasi hasil self regulation learning menggunakan instrumen post-test, dan untuk mengetahui respon peserta didik diobservasi menggunakan instrumen respon peserta didik.

Tahapan refleksi dilaksanakan dengan cara mencermati hasil dari tindakan siklus I dan hasil diskusi dengan observer. Jika ditemukan hal-hal yang harus diperbaiki, maka guru BK menyusun kembali rencana layanan bimbingan belajar daring model STAD berbantuan media thinglink yang akan dilaksanakan di siklus II dengan memperhatikan masukan dari observer.

\section{Tahapan tindakan siklus II}

Tahapan siklus II dilaksanakan seperti tahapan siklus I, dengan melakukan beberapa tindakan perbaikan. Pada tahap perencanaan; guru BK Menyusun RPL-BK sesuai sintak STAD berbantuan media thinglink dengan memperhatikan hasil refleksi pada siklus I, mengunggah link media thinglink, LKPD self regulation learning, LKK, post-test, angket respon peserta didik, dan menginformasikan link untuk google meeting di grup kelas. Perbaikan dilaksanakan pada sintak ketiga yakni presentasi dari guru. Media thinglink yang digunakan memakai gambar-gambar yang lebih menarik, narasi/penjelasan materi dilengkapi dengan audio secara keseluruan, dan dipilihkan video motivasi yang inspiratif bagi peserta didik.

Tahapan tindakan pada pertemuan 3 dilaksanakan hari Kamis, 6 Mei 2021 selama 3 jam pelajaran melalui aplikasi google classroom, diawali dengan google meeting dilanjutkan dengan belajar secara interaktif dengan menggunakan media thnglink. Indikator kompetensi dasar bimbingan: penerapan self regulation learning dalam mencapai target belajar. Kegiatan layanan bimbingan belajar daring dilaksanakan dengan sintak STAD. Dengan media thinglink peserta didik dibimbing untuk menerapkan aspek self regulation learning dalam membuat strategi belajarnya, mengerjakan LKPD, dan dimantapkan untuk lebih memahami prosedur belajar dalam tim secara daring yang efektif.

Tahapan tindakan pertemuan 4 dilaksanakan hari Jumat, 7 Mei 2021 selama 3 jam pelajaran pelajaran melalui aplikasi google classroom dan diawali dengan google meeting. Indikator kompetensi dasar bimbingan: upaya mengatasi kesulitan belajar berdasarkan self regulation learning. Kegiatan layanan bimbingan belajar daring dilaksanakan dengan sintak STAD. Perbaikan tindakan dilakukan pada sintak keempat yakni kegiatan belajar dalam tim. Pada tahap ini guru BK lebih intensif memantau aktivitas belajar setiap tim, dengan melakukan koordinasi semua ketua tim melalui pesan WhatsApp dan video call.

Tahapan penelitian selanjutnya adalah observasi; dilakukan dengan cara melakukan pengamatan aktivitas guru BK dalam menyampaikan layanan bimbingan belajar daring model STAD berbantuan media thinglink dengan menggunakan instrumen aktivitas guru BK. Selanjutnya aktivitas peserta didik dalam mengikuti layanan bimbingan belajar daring model STAD berbantuan media thinglink diobservasi menggunakan instrumen aktivitas 
peserta didik. Untuk mengobservasi hasil self regulation learning menggunakan instrumen posttest. Respon peserta didik diobservasi menggunakan angket respon peserta didik.

Tahapan refleksi pada siklus II merupakan kegiatan yang dilakukan untuk memperbaiki tindakan yang telah direncanakan sebelumnya. Proses refleksi siklus II dilakukan secara menyeluruh dengan tujuan untuk menilai hasil tindakan yang telah dilakukan (Warso, 2018:38). Apakah hasil tindakan secara konsisten telah mencapai tujuan penelitian yakni meningkatkan self regulation learning peserta didik.

Data yang diperlukan dalam penelitian ini antara lain; data aktivitas guru BK dalam menyampaikan layanan, data aktivitas peserta didik dalam mengikuti layanan, data hasil self regulation learning, dan data respon peserta didik dalam mengikuti layanan. Data keterlaksanaan layanan bimbingan belajar daring model STAD berbantuan media thinglink, diperoleh dengan observasi menggunakan instrument aktivitas guru BK dan instrument aktivitas peserta didik, dilengkapi pula dengan dokumen tangkapan layar (screenshot) penerapan layanan bimbingan belajar daring sesuai sintak STAD dengan berbantuan media thinglink. Data respon peserta didik diobservasi dengan angket respon peserta didik. Selanjutnya untuk mengetahui hasil atau kemampuan self regulation learning peserta didik, diobservasi dengan tes terulis menggunakan instrumen pre-test dan post-test yang disusun menggunakan skala likert. Pada skala likert variabel yang akan diukur diuraikan kedalam indikator variabel sebagai acuan dalam membuat item instrumen berupa pertayataan atau pernyataan yang harus dijawab peserta didik (Widoyoko, 2018: 104).

Teknik analisis data yang digunakan adalah teknik deskriptif; yakni kajian yang mencoba menjelaskan suatu fenomena, peristiwa, gejala dengan menggunakan data kualitatif maupun kuantitatif (Sugiono, 2014: 336). Teknik deskriptif mencoba menjelaskan obyek atau subyek yang diselidiki dengan apa adanya (Sukardi, 2014: 162). Teknik deskriptif kualitatif digunakan untuk memaparkan data pelaksanaan layanan bimbingan belajar daring model STAD berbantuan media thinglink, dari perencanaan, pelaksanaan tindakan, observasi dan refleksi pada siklus I dan II. Teknik deskriptif kualitatif digunakan pula untuk menjelaskan data keaktifan peserta didik dalam mengikuti layanan, serta untuk mejelaskan data respon peserta didik. Teknis analisis data deskriptif kuantitatif dipakai untuk menjelaskan hasil tindakan yang berpatokan pada tujuan penelitian yaitu meningkatnya self regulation learning dengan cara menganalisis data pre-test, post-test 1 dan post-test 2 dengan mengacu pada indikator keberhasilan penelitian yang ditetapkan.

Indikator keberhasilan dalam penelitian ini adalah terjadinya peningkatan pada indikator metakognisi, motivasi dan perilaku. Dikatakan meningkat jika indikator metakognisi mencapai $85 \%$, indikator motivasi mencapai $85 \%$ dan indikator perilaku mencapai $85 \%$. Penelitian ini dikatakan berhasil apabila mencapai indikator keberhasilannya yaitu $85 \%$ untuk aspek metakognisi, $85 \%$ untuk motivasi, dan 85\% untuk aspek perilaku.

\section{Hasil dan Pembahasan}

PTK BK ini dilaksanakan dalam dua siklus, setiap siklus dilaksanakan dua kali pertemuan, masing-masing pertemuan selama tiga jam pelajaran. Fokus PTK BK ini adalah peningkatkan self regulation learning melalui layanan bimbingan belajar daring model STAD berbantuan media thinglink.

Siklus I layanan bimbingan belajar daring model STAD berbantuan media thinglink diawali dengan perencanaan meliputi: menyusun silabus, RPL BK, media thinglink, membuat LKPD, LKK, membuat kelompok daring di google classroom, format presensi, instrumen self regulation learning, instrument aktivitas guru BK dan instrument aktivitas peserta didik. Pada tahap pelaksanaan tindakan diawali dengan kegiatan pendahuluan; melalui aplikasi google meeting guru BK, menyampaikan salam, berdoa, meminta peserta didik presensi di google classroom dan melakukan apersepsi.

Pada kegiatan inti guru BK menyampaikan layanan bimbingan belajar dengan sintak STAD yakni: Pertama, guru BK menyampaikan tujuan mempelajari self regulation learning dan memotivasi peserta didik untuk mengikuti kegiatan dengan sungguh-sungguh, kegiatan peserta didik memperhatikan penjelasan dari guru BK.

Sintak kedua pembagian kelompok, guru BK menjelaskan pembagian kelompok dan Langkahlangkah belajar dalam tim secara daring yang efektif, kegiatan peserta didik memperhatikan penjelasan guru BK dan mengecek pembagian kelompok di google classroom.

Sintak ketiga presentasi guru BK, melalui media thinglink peserta didik belajar secara interaktif tentang materi self regulation learning dan aspek-aspeknya, dilanjutkan mengerjakan LKPD tentang pemahaman self regulation learning dengan melakukan penilaian terhadap dirinya sendiri dari sudut aspek metakognisi, motivasi 
dan perilakunya dalam pembelajaran daring selama ini, kemudian mengirim ulang hasil LKPD di google classroom.

Sintak keempat kegiatan belajar dalam tim, peserta didik belajar dalam tim secara daring dengan panduan LKK untuk: menganalisis kesulitan yang dialaminya selama pembelajaran daring, menjelaskan upaya-upaya yang sudah dilakukan untuk mengatasi permasalah tersebut, dan membuat target belajar yang akan dicapai. Pada saat peserta didik belajar dalam tim, guru BK memantau melalui pesan WhatsApp grup kelas.

Sintak kelima evaluasi, guru BK mengevaluasi LKPD dan LKK yang dikirim ulang di google classroom. Terakhir sintak keenam penghargaan, guru BK memberi penghargaan secara individu bagi peserta didik yang mengumpulkan LKPD tepat waktu dan benar, dan memberi penghargaan secara kelompok untuk LKK yang dikumpulkan tepat waktu, lengkap dan benar.

Tahap observasi dilakukan untuk mendapatkan hasil penelitian yang ditujukan pada peserta didik dengan cara meminta peserta didik mengerjakan intrumen self regulation learning sebagai post-test I, observasi juga dilakukan untuk mengetahui proses guru BK dalam menyampaikan layanan bimbingan belajar model STAD berbantuan media thinglink, dan untuk mengetahui aktivitas peserta didik dalam mengikuti layanan bimbingan belajar.

Hasil self regulation learning dilihat berdasarkan 3 indikator yakni metakognisi, motivasi dan perilaku sebagai berikut: Pertama. pada metakognisi indikator keberhasilannya adalah: 1). Memahami kemampuan berfikir dalam menyelesaikan tugas-tugas belajar. 2). Mempertimbangkan tingkat kemampuan berfikir saya dalam mempersiapkan ulangan. 3). Mampu membuat strategi belajar sesuai kemamuan berfikir yang saya dimiliki. 4). Mampu memahami cara mengerjakan tugas-tugas sesuai kemampuan kognitif saya. 5). Dengan memahami tingkat kemampuan kognitif, saya dapat mengatasi kesulitan belajar.

Kedua, indikator keberhasilan pada motivasi meliputi: 1). Tanpa disuruh saya mengerjakan tugas-tugas yang diberikan guru. 2). Saya mengumpulkan tugas sebelum batas akhir. 3). Terdorong untuk mewujudkan target/tujuan belajar yang saya tetapkan. 4). Memahami hambatan yang saya alami dalam mewujudkan target/tujuan. 5). Mampu mengatasi hambatan yang saya alami dalam mewujudkan target / tujuan belajar.
Ketiga, indikator keberhasilan pada perilaku meliputi: 1). Mampu memanfaatkan teknologi untuk mendukung terwujudnya target/tujuan belajar. 2). Mempunyai jadwal belajar yang mengarah terwujudnya target / tujuan yang telah ditetapkan. 3). Membaca buku-buku literatur yang mendukung dalam belajar. 4). Bisa fokus belajar tanpa terganggu sosial media yang ada. 5). Ruang belajar saya rapi, bersih, sirkulasi udara cukup dan nyaman.

Untuk mengetahui hasil self regulation learning peserta didik, dapat dilakukan dengan cara membandingkan hasil self regulation learning dari sebelum tindakan dengan setelah dilakukan tindakan siklus I, dapat dilihat pada tabel 1 berikut.

Tabel 1. Perbandingan hasil self regulation learning peserta didik sebelum tindakan dengan setelah tindakan siklus I.

\begin{tabular}{crcc}
\hline \multirow{2}{*}{ No. } & \multirow{2}{*}{ Indikator } & \multicolumn{2}{c}{ Persentase } \\
\cline { 3 - 4 } & & Pre-test & Siklus I \\
\hline 1. & Metakognisi & 77.20 & 85.50 \\
2. & Motivasi & 76.70 & 85.50 \\
3. & Perilaku & 74 & 81.10 \\
\hline
\end{tabular}

Dari data tersebut dapat terlihat bahwa ada peningkatan hasil dari sebelum tindakan, dengan sesudah dilaksanakan layanan bimbingan belajar daring model STAD berbantuan media thinglink. Pada indikator metakognisi sebelum tindakan berada pada posisi $77.20 \%$ dan setelah tindakan siklus I mencapai $85.50 \%$. Hal ini menunjukan bahwa aspek metakognisi peserta didik meningkat $8.30 \%$. Selanjutnya pada indikator motivasi sebelum tindakan berada pada posisi $76.70 \%$ dan setelah dilakukan tindakan siklus I mencapai $85.50 \%$. Hal ini menunjukkan aspek motivasi peserta didik meningkat $8.80 \%$.

Pada indikator perilaku peserta didik sebelum tindakan $41.70 \%$, setelah dilakukan tindakan siklus I meningkat menjadi $46.70 \%$. Jika dikaitkan dengan indikator keberhasilan pada aspek perilaku dari pengolahan jawaban selalu dan sering, sebelum tindakan berada pada posisi $74 \%$ dan setelah dilakukan tindakan siklus I mencapai $81,10 \%$. Hal ini menunjukkan aspek perilaku peserta didik meningkat $7.10 \%$.

Dari pemaparan di atas diperoleh gambaran bahwa dari semua aspek self regulation learning peserta didik sudah mengalami peningkatan, namun yang memenuhi indikator keberhasilan penelitian baru metakognisi dan motivasi masingmasing mencapai $85.50 \%$. Untuk perilaku belum memenuhi indikator keberhasilan penelitian dikarenakan baru mencapai 81,10\%. 
Hasil observasi proses pelaksanaan layanan bimbingan belajar daring model STAD berbantuan media thinglink, guru BK sudah melaksanakan melaksanakan kegiatan sesuai dengan Langkah-langkah yang direncanakan dalam RPL BK. Untuk keterlibatan peserta didik dalam pelaksanaan layanan bimbingan belajar daring model STAD berbantuan media thinglink $83.33 \%$ peserta didik terlibat aktif dalam kegiatan.

Tahap refleksi dengan melakukan pencermatan lagi pada indikator keberhasilan penelitian terutama pada indikator perilaku. Tujuan dari refleksi ini untuk mengetahui kendala yang ditemukan pada siklus I. Hasilnya ditemukan data pada indikator perilaku sebagai berikut: 1). Mampu memanfaatkan teknologi untuk mendukung terwujudnya target/tujuan belajar mencapai $86.10 \%$. 2). Mempunyai jadwal belajar yang mengarah terwujudnya target /tujuan yang telah ditetapkan sebesar $80.56 \%$. 3). Membaca buku-buku literatur yang mendukung dalam belajar $77.78 \%$ 4). Bisa fokus belajar tanpa terganggu sosial media memperoleh $75 \%$ 5). Ruang belajar saya rapi, bersih, sirkulasi udara cukup dan nyaman mencapai $86.10 \%$.

Berdasarkan masukan dan diskusi dengan observer, maka guru BK menyusun langkahlangkah perbaikan tidakan yang akan dilaksanakan di siklus II untuk memecahkan permasalahan tersebut. Langkah-langkah tindakan perbaikan yang dilakukan pada tahap perencanaan dengan membuat RPL BK dengan materi yang yang aktual dan menggunakan media thinglink yang menarik.

Kemudian langkah perbaikan juga peneliti lakukan pada sintak ketiga yaitu pada tahap presentasi dari guru; media thinglink yang digunakan memakai gambar-gambar yang lebih menarik, pada narasi/penjelasan materi dilengkapi dengan audio secara keseluruan, dan memakai video motivasi yang inspiratif; terdapat part dimana tokoh tersebut berjuang mengatasi kegagalannya, sampai proses mencapai kesuksesannya yang mendunia.

Kemudian pada sintak keempat tahap belajar dalam tim, guru BK lebih intensif dalam memantau aktivitas belajar setiap tim, dengan melakukan koordinasi dengan setiap ketua tim melalui pesan WhatsApp dan video call, untuk membimbing dan memberi bantuan jika ada tim yang mengalami kesulitan dalam menyelesaikan tugas belajarnya. Contoh perbaikan yang dilakukan peneliti pada sintak ketiga; presentasi dari guru BK seperti pada gambar 1, 2, 3, 4, 5, dan 6 berikut.

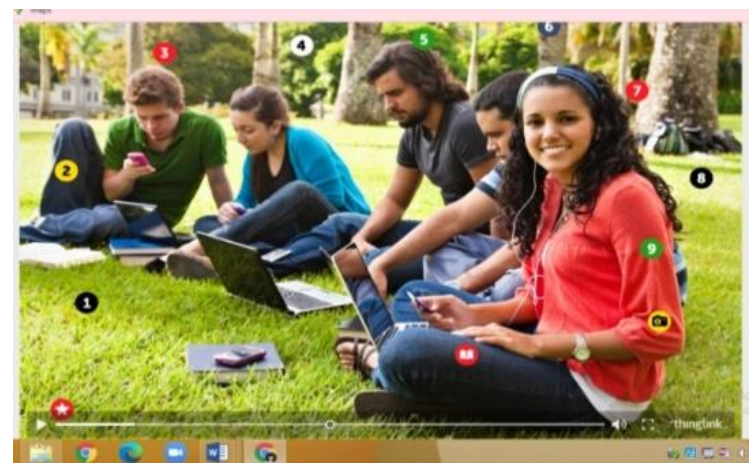

Gambar 1. Materi Self regulation learning dalam media thinglink dengan gambar yang menarik dan untuk belajar siswa tinggal mengklik tombol warna-warni sesuai urutan nomor yang ada.

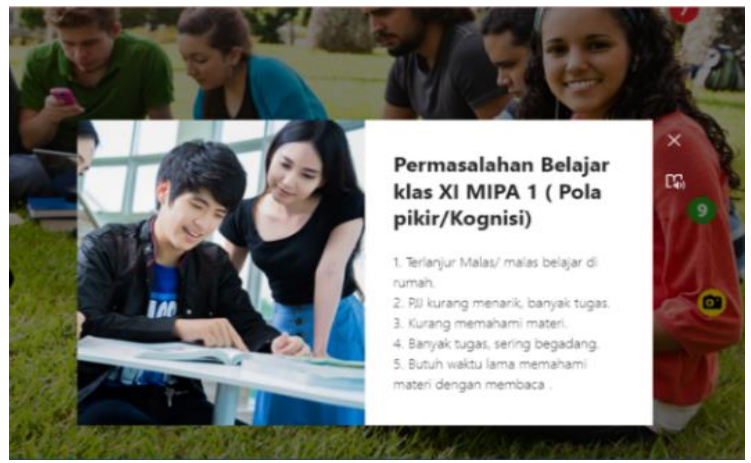

Gambar 2. Melalui media thinglink peserta didik dibimbing untuk mendalami aspek metakognisi

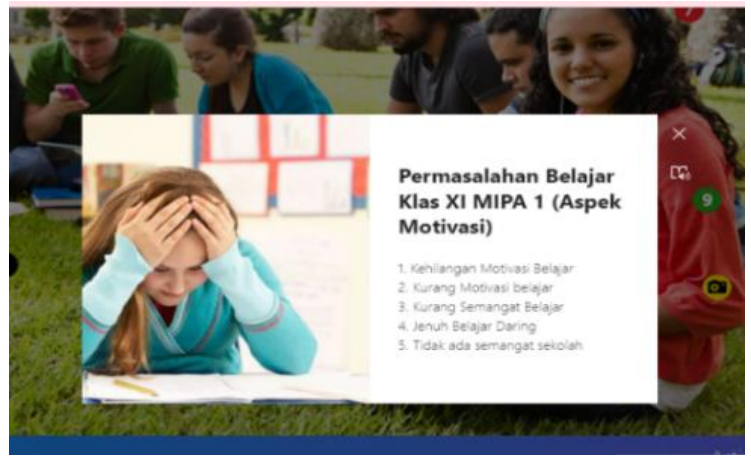

Gambar 3. Melalui media thinglink peserta didik dibimbing untuk mendalami aspek motivasi

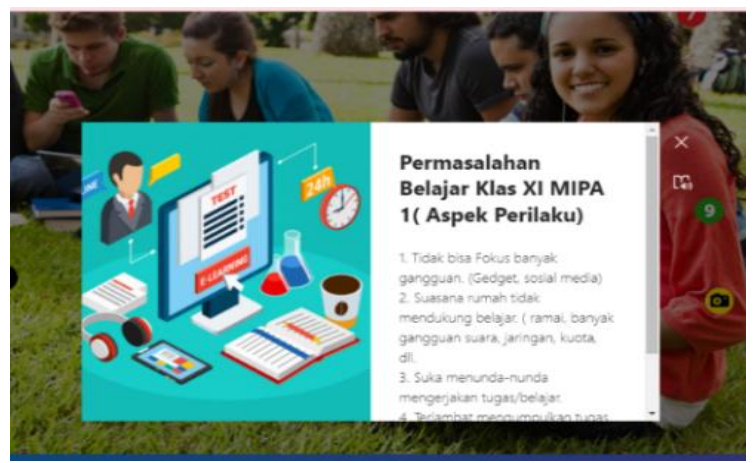

Gambar 4. Melalui media thinglink peserta didik dibimbing untuk mendalami aspek perilaku 


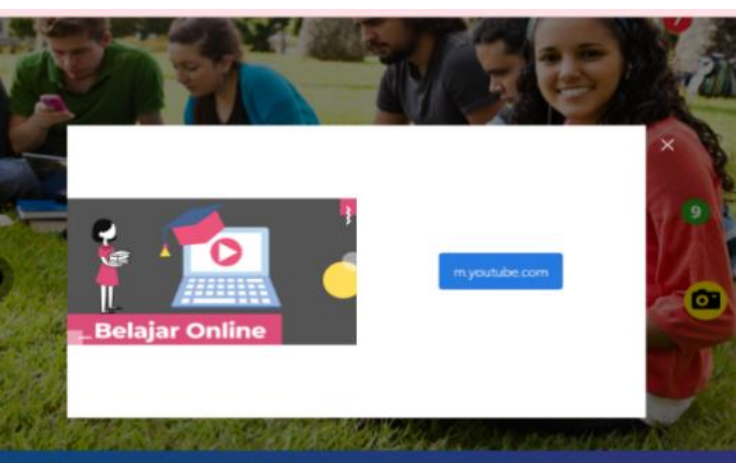

Gambar 5. link video motivasi

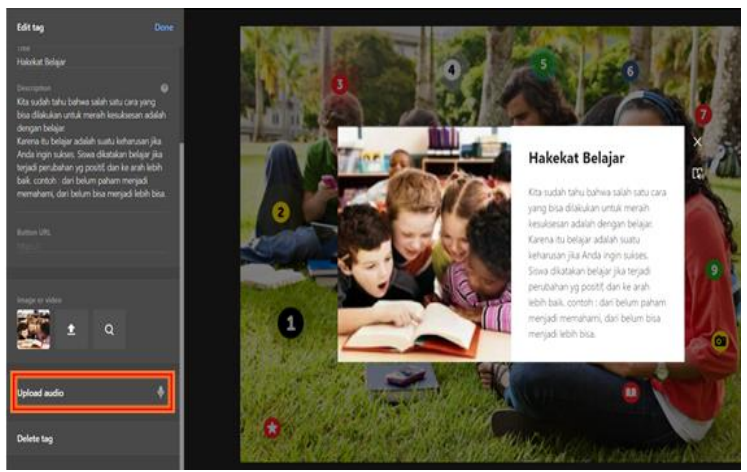

Gambar 6. Contoh proses upload audio

Merujuk pada penelitian yang dilakukan Kusumawardani dkk. (2018) mengatakan bahwa pembelajaran dengan menggunakan media poster pada model kooperatif tipe STAD efektif terhadap hasil belajar peserta didik. Hal tersebut telah dibuktikan dalam pengujian hipotesis yang menjelaskan bahwa nilai lebih kecil dari nilai $(1,74<4,28)$ yang artinya Ho diterima dan Ha ditolak.

Hasil penelitian tersebut mendorong peneliti untuk menyampaikan layanan bimbingan belajar daring model STAD berbantuan media thinglink kepada peserta didik dengan baik. Maka peneliti berusaha mempersiapkan diri dengan sebaik-baiknya dengan upaya: membuat RPL BK sesuai sintak, menguasai langkah-langkah model STAD dengan baik, memilih materi yang aktual dan menggunakan media yang menarik. Pada penelitian Kusumawardani dkk. (2018) menggunakan media pembelajaran berupa poster, sedangkan pada PTK BK ini peneliti memilih menggunakan media pembelajaran online yang aktual yakni media pembelajaran interaktif dengan menggunakan media thinglink.

Selanjutnya pada siklus II guru BK melaksanakan layanan bimbingan belajar daring model STAD berbantuan media thinglink dengan memperhatikan hasil refleksi pada siklus I dan masukan dari observer. Maka pada tahap persiapan guru BK menyusun RPL BK dengan beberapa tindakan perbaikan. Tahap tindakan, observasi dan refleksi dilakukan hampir sama dengan siklus I pada tahan tindakan ada upaya perbaikan tindakan pada sintak ketiga; presentasi dari guru dan sintak keempat kegiatan belajar dalam tim.

Untuk mengetahui hasil self regulation learning peserta didik pada siklus II dapat dilihat pada tabel 2 berikut.

Tabel 2. Hasil self regulation learning peserta didik setelah tindakan siklus I.

\begin{tabular}{clc}
\hline \multirow{2}{*}{ No } & \multirow{2}{*}{ Indikator } & Persentase \\
\cline { 3 - 3 } & & Siklus II \\
\hline 1. & Metakognisi & 89.90 \\
2. & Motivasi & 87.40 \\
3. & Perilaku & 83.30 \\
\hline
\end{tabular}

Untuk mengetahui hasil self regulation learning peserta didik setelah mengikuti tindakan siklus I dan setelah mengikuti tindakan siklus II dapat dicermati dari tabel 3 berikut.

Tabel 3. Perbandingan hasil self regulation learning peserta didik siklus I dengan setelah siklus II.

\begin{tabular}{llcc}
\hline \multirow{2}{*}{ No } & \multirow{2}{*}{ Indikator } & \multicolumn{2}{c}{ Persentase } \\
\cline { 3 - 4 } & & Siklus I & Siklus II \\
\hline 1. & Metakognisi & 85.50 & 89.90 \\
2. & Motivasi & 85.50 & 87.40 \\
3. & Perilaku & 81.10 & 83.30 \\
\hline
\end{tabular}

Berdasarkan data pada tabel 3, indikator metakognisi peserta didik siklus I berada pada posisi $85.50 \%$ dan setelah dilakukan tindakan siklus II meningkat mencapai $89.90 \%$. Hal ini menggambarkan bahwa aspek metakognisi peserta didik meningkat sebesar 4.40\%. Sedangkan pada idikator motivasi peserta didik setelah siklus I $85.50 \%$, setelah dilakukan tindakan siklus II meningkat menjadi $87.40 \%$. Peningkatan pada indikator aspek motivasi sebesar $1.9 \%$.

Indikator terakhir dalam self regulation learning adalah perilaku. Dari data tersebut menunjukkan bahwa aspek perilaku peserta didik setelah mengikuti tindakan siklus I mencapai $81.10 \%$, dan setelah peserta didik selesai mengikuti tindakan siklus II meningkat menjadi $83.30 \%$. Peningkatan indikator pada aspek perilaku meningkat $2.20 \%$. Namun belum memenuhi indikator keberhasilan yang ditetapkan.

Perolehan data secara rinci pada perilaku bisa dicermati dari lima indikator perilaku jika dibandingkan setelah tindakan siklus I dan setelah tindakan siklus II, seperti tampak pada tabel 4 berikut. 
Tabel 4. Perbandingan hasil self regulation learning pada indikator perilaku siklus I dan II.

\begin{tabular}{lcc}
\hline \multicolumn{1}{c}{ Indikator Perilaku } & Siklus I & Siklus II \\
\hline $\begin{array}{l}\text { 1. Mampu memanfaatkan } \\
\text { teknologi untuk }\end{array}$ & $86.10 \%$ & $86.10 \%$ \\
mendukung terwujudnya \\
target/tujuan belajar. \\
$\begin{array}{l}\text { 2. Mempunyai jadwal } \\
\text { belajar yang mengarah } \\
\text { terwujudnya target } \\
\text { /tujuan yang telah } \\
\text { ditetapkan }\end{array}$ & $80.56 \%$ & $86.10 \%$ \\
$\begin{array}{l}\text { 3. Membaca buku-buku } \\
\text { literatur yang } \\
\text { mendukung dalam } \\
\text { belajar }\end{array}$ & & \\
$\begin{array}{l}\text { 4. Bisa fokus belajar tanpa } \\
\text { terganggu sosial media }\end{array}$ & $75 \%$.78\% & $80.56 \%$ \\
$\begin{array}{l}\text { yang ada. } \\
\text { 5uang belajar saya rapi, } \\
\text { bersih, sirkulasi udara } \\
\text { cukup dan nyaman. }\end{array}$ & $86.10 \%$ & $86.10 \%$ \\
\hline
\end{tabular}

Dari data pada tabel 4 di atas dapat kita cermati bahwa terdapat dua indikator perilaku yang sudang memenuhi kriteria indikator keberhasilan penelitian yakni pada indikator: Mampu memanfaatkan teknologi untuk mendukung terwujudnya target/tujuan belajar, mempunyai jadwal belajar yang mengarah terwujudnya target /tujuan yang telah ditetapkan, dan indikator ruang belajar saya rapi, bersih, sirkulasi udara cukup dan nyaman. Sedangkan indikator perilaku yang belum memenuhi adalah indikator: membaca bukubuku literatur yang mendukung dalam belajar siklus I 77.78\% setelah siklus II menjadi $80.56 \%$ meningkat sebesar $2.78 \%$. Untuk indikator bisa fokus belajar tanpa terganggu sosial media yang ada siklus I memperoleh $75 \%$ setelah tindakan siklus II menjadi $77.78 \%$, meningkat sebesar $2.78 \%$. Hal ini dikarenakan peserta didik belum bisa sepenuhnya untuk fokus pada aktifitas belajarnya, gangguannya yang sering dialami terletak pada belum sepenuhnya mampu memanfaatkan sosial media dengan bijak agar mendukung target belajarnya. Kendala selanjutnya peserta didik kurang membaca bukubuku literatur yang mendukung dalam belajar. Kondisi ini kurang lebih sama dengan hasil wawancara pada latar belakang di atas peserta didik mengeluhkan: 1) mulai merasa jenuh dan bosan mengikuti pembelajaran daring karena bayak tugas, 2) sering tergoda menghabiskan waktu untuk bermain gadget, 3) kurang konsentrasi saat mengikuti layanan bimbingan belajar, 4) merasa kesulitan mengelola aktivitas belajarnya sehingga tidak maksimal dalam menyelesaikan tugas-tugas yang menjadi tanggungjawabnya. Hal ini karenakan belum semua peserta didik mampu mengatur lingkungan dan memfokuskan kegiatannya pada pencapaian target belajar. Selain itu untuk mengubah perilaku kearah lebih baik, membutuhkan proses bertahap maka peserta didik perlu dibimbing secara intensif kedepannya, agar sungguh-sungguh mampu fokus dan dapat melakukan kegiatan yang mendukung target belajarnya, dan mendorong peserta didik secara terus menerus untuk menumbuhkan budaya membaca, sehingga nilai self regulation learning bisa menjadi prinsip hidup yang dimiliki oleh semua peserta didik. Karena aspek perilaku berkaitan dengan upaya peserta didik untuk mengatur diri, mengelola, memanfaatkan dan menciptakan lingkungan yang mendukung aktivitas belajarnya (Zimmerman, dalam Yasdar dan Muliyadi, 2018: 52).

Berdasarkan hasil pengamatan dari observer dan dipadukan dengan instrumen respon peserta didik dalam mengikuti layanan bimbingan belajar daring model STAD berbantuan media thinglink setelah tindakan siklus II, dari 15 pertanyaan terdapat 8 pertanyaan yang memperoleh skor diatas 90\% yaitu: Lebih bisa memahami kemampuan kognitif/metakognisi 91.70\%. Memahami tujuan belajar yang akan saya capai $94.40 \%$. Berani untuk mengemukakan pendapat $91.70 \%$. Lebih dekat/akrab dengan teman-teman sebesar $91.70 \%$. Menghargai pendapat orang lain $91.70 \%$. Aktif terlibat dalam belajar di tim 91.70\%. Diterima oleh temanteman dalam tim $94.40 \%$. Dan lebih termotivasi dalam mencapai target belajar sebesar $94.40 \%$. Hal ini menunjukkan bahwa model pembelajaran tipe STAD berbantuan media thinglink menarik dan menyenangkan bagi peserta didik walaupun disajikan secara daring.

\section{Simpulan dan Saran}

Berdasarkan hasil penelitian tindakan kelas bimbingan konseling yang sudah dilaksanakan maka dapat disimpulkan bahwa hasil dari penerapan layanan bimbingan belajar daring model STAD berbantuan media thinglink dapat meningkatkan self regulation learning peserta didik pada kelas XI MIPA-1 SMA Negeri 2 Yogyakarta Tahun Ajaran 2020/2021.

Pada akhir proses pelaksanaan siklus II pemahaman semua indikator self regulation learning peserta didik mengalami peningkatan. Pada metakognisi peserta didik berada pada 
posisi $85.50 \%$ dan setelah dilakukan tindakan siklus II mencapai $89.90 \%$. Hal ini menggambarkan bahwa metakognisi peserta didik meningkat sebesar $4.40 \%$. Pada indikator motivasi peserta didik pada siklus I berada pada posisi $85.50 \%$, setelah dilakukan tindakan siklus II meningkat menjadi $87.40 \%$, peningkatan pada indikator aspek motivasi sebesar $1.9 \%$. Selanjutnya pada indikator perilaku peserta didik setelah mengikuti siklus I diperoleh data sebesar $81.10 \%$ dan setelah selesai mengikuti tindakan siklus II meningkat menjadi $83.30 \%$. Peningkatan indikator keberhasilan pada aspek perilaku meningkat $2.20 \%$, walaupun masih belum memenuhi indikator keberhasilan yang ditetapkan dalam penelitian ini yakni 85\%.

Berdasarkan analisis data respon peserta didik dari 15 pertanyaan terdapat 8 pertanyaan yang memperoleh skor diatas $90 \%$ dari skor maksimal yang ditetapkan 100. Dari perolehan data tersebut dapat disimpulkan bahwa hipotesis tindakan yang diajukan peneliti dapat terbukti, bahwa layanan bimbingan belajar daring model STAD berbantuan media thinglink dapat meningkatkan self regulation learning peserta didik kelas XI MIPA-1 SMA Negeri 2 Yogyakarta. Peningkatan self regulation learning dari sebelum tindakan dibandingkan dengan setelah tindakan siklus II, pada aspek metakognisi meningkat $12.70 \%$, untuk aspek motivasi meningkat $10.70 \%$, aspek perilaku meningkat menjadi $9.30 \%$.

Berdasarkan hasil penelitian tindakan kelas bimbingan konseling peningkatan self regulation learning melalui layanan bimbingan belajar daring model STAD berbantuan media thinglink, maka peneliti sarankan untuk diadakan penelitian dengan model pembelajaran lain yang dapat digunakan sebagai alternatif untuk meningkatkan self regulation learning peserta didik. Pentingnya peneliti memiliki sikap yang dinamis dalam memahami peserta didik, dengan selalu memperhatikan perkembangan psikologi peserta didik diharapkan penanaman nilai-nilai self regulation learning dapat disampaikan sesuai dengan situasi dan kondisi perserta didik sehingga lebih mengena dan mudah dipahami. Untuk menanamkan aspek self regulation learning sebagai budaya hidup, peserta didik perlu dibimbing dan diingatkan dengan model pembelajaran yang menarik agar peserta didik semangat melaksanakannya, serta perlu dipantau secara terus-menerus terutama pada aspek perilaku agar dapat diterapkan secara sungguhsungguh sehingga menjadi nilai/budaya hidup yang akan diterapkan peserta didik dimanapun dia berada.

\section{Daftar Pustaka}

Kemendikbud. (2020). Surat Edaran Nomor: 15 Tahun 2020 tentang Pedoman Penyelenggaraan Belajar dari Rumah Dalam Masa Darurat penyebaran Corona VirusDisease. Jakarta: Kemendikbud.

Kusumawardani dkk. (2018). Pengaruh model Pembelajaran Kooperatif Tipe STAD Berbantuan Media Poster Terhadap Hasil Belajar Peserta Didik. Semarang: Jurnal Ilmiah Sekolah dasar, 2(2), 170-174. https://ejurnal.undiksha.ac.id/index.php/JI $\mathrm{SD} /$ index

Nasution, HS dan Abdillah. (2019). Bimbingan Konseling Konsep dan Aplikasinya. Medan: LPPI.

Rusman. (2012). Model-Model Pembelajaran Mengembangkan Profesionalitas Guru. Depok: Raja Grafindo Perkasa.

Sukiman. (2011). Penelitian Tindakan Kelas Untuk Guru Pembimbing. Yogyakarta: Paramitra.

Sukardi. (2014). Metodologi Penelitian Pendidikan. Jakarta: Bumi Aksara.

Savira F dan SuharsonoY. (2013). Self Regulated Learning (SRL) Dengan Prokrastinasi Akademik Pada Siswa Akselerasi. Malang: Jurnal Ilmiah Psikologi Terapan, 1(1), 66-75. https://ejournal.umm.ac.id/index.php/jipt/ article/view/1358.

Shoimin, Aris. (2013). Model Pembelajaran Inovatif. Yogyakarta: Ar-Ruzz Media

Sanjaya, Wina. (2013). Strategi Pembelajaran Beroreintasi Standar Proses. Jakarta: Kencana.

Sugiono. (2014). Cara Mudah Menyusun Skripsi, Tesis, dan Desertasi. Bandung: Alfabeta.

Widoyoko, Eko Putro. 2017. Teknik Penyusunan Instrumen Penelitian. Yogyakarta: Pustaka Pelajar.

Warso, Agus Wasisto Dwi Doso. (2018). Cara Mudah Melakukan Penietitian Tindakan Kelas. Yogyakarta: Graha Cendekia.

Yasdar dan Muliyadi. (2018) Peningkatan Teknik Regulasi Diri (Self Regulation) Untuk Maningkatkan Kemandirian Belajar Mahasiswa Program Studi Bimbingan Konseling STKIP Muhammadiyah Enrekang. Jurnal Edumaspul, 2(2), 51-60. https://ummaspul.e-jurnal.id

Zain Fuadi. (2020). Belajar Interaktif Menggunakan Thinglink. Diakses dari https://www.youtube.com/watch?v=Wt94 GBB6bX 